\title{
A Milestone Work in the Historiography of American Literature in China:
}

\section{A Review of The History of Hispanic American Literature}

\author{
WANG Zuyou \\ School of Foreign Languages, Taizhou University \\ Received: April 10, 2021 \\ Accepted: May 6, 2021 \\ Published: August 30, 2021
}

To cite this article: WANG Zuyou. (2021). A milestone work in the historiography of American literature in China: A review of The History of Hispanic American Literature. Asia-Pacific Journal of Humanities and Social Sciences, 01:2, 028-034, DOI:10. 53789/ j.1653-0465.2021.0102.003

To link to this article: https://doi.org/10.53789/ j.1653-0465.2021.0102.003

\begin{abstract}
The History of Hispanic American Literature (2021) is an epochal work in the historiography of American literature. This book uses ethnic literature categories and chronological periodization as the horizontal and vertical axes, respectively. It selects representative works of writers as typical research examples and makes a comprehensive investigation from the aspects of social history, literary trend, artistic representation and aesthetic orientation. The monograph systematically sorts out the development and evolution of Hispanic American literature from 1872 to 2019 , focusing on the combination of historical retrospect and literary criticism and the combination of panoramic overview and representative cases. The book has four characteristics. Firstly, it is a pioneering work consisting of rich first-hand materials with novel content, which is the first one in Hispanic American literary study. Secondly, it is researchoriented and rigorously elaborated, which fully shows the distinctive features, representative style, influence and literary status of the research object in each period. Thirdly, it is objective. The author thinks and judges from different standpoints, not affected by subjective thoughts or consciousness in exploring Chicano literature. The fourth one is to analyze writers and works dialectically from multiple perspectives and historical contexts, focusing on horizontal and vertical comparisons. This book has reached a high academic level and has made a significant contribution to the study of American literature in China.
\end{abstract}

Keywords: The History of Hispanic American Literature; pioneering; research-oriented; objective; dialectical

Notes on the contributor: WANG Zuyou is professor of English at the School of Foreign Language, Taizhou University ( Taizhou 225300, China). His research is focused on American literature and western literary theory.

The development of ethnic literature is inseparable from the growing influence of ethnic groups. The literature of Hispanic Americans, a minority group in the United States with the largest population, plays an increasingly important role in social life. Hispanic American literature originated earlier than white American literature, and its culture is an important part of multi-ethnic American culture. However, it was not until the first half of the 20th century that their English literature began to merge into mainstream American literature, as most Hispanic groups are native speakers of Spanish. Under the influence of the Chicano Movement in the 1960s, 
Hispanic American literature has made remarkable achievements and has been widely recognized. Chinese scholars have recently begun to recognize its value. Professor Li Baojie's The History of Hispanic American Literature (2021) is the first work on the history of Hispanic American literature compiled in China. Apart from the epilogue, reference, appendix and postscript, the book is divided into eight chapters. It traces the cultural origin of Hispanic literature from a macro perspective and comprehensively introduces the general situation and various branches of American Hispanic literature, taking into account the historical development of literature, the actual situation and trends in development. It also makes an objective evaluation and a comprehensive and indepth analysis of the latest literature situation. This book focuses on the literary expression of the writer's diaspora experience and exile identity, the construction of the character's multi-cultural identity and diversified narrative style, and the negotiation between the "ethnicity" and "Americanism" of American literature. The first chapter is an overview of American Hispanic literature, including its definition, classification and research status. The second chapter introduces the origin and early course of Mexican literature, especially the Chicano literary movement and its influence. The third chapter discusses the "Depoliticization" theme of contemporary Mexican literature, the rise of female writing and the epochal nature of literature in the new century. The fourth chapter discusses Puerto Rican American literature, focusing on "the combination of Hispanic reality and European literary tradition" and "Puerto Rican female literature and female identity writing". The fifth chapter discusses the origin and exile mode of Cuban literature, highlighting the textualization of Cuban exile mode and the counterexile writing trend. The sixth chapter focuses on the pluralistic orientation of contemporary Cuban literature, such as "the negotiation between the 1.5 generation writers and the exile model", and new literature and popular literature. Chapter seven discusses Caribbean immigrant literature and Caribbean literature. The eighth chapter reviews South American immigrant literature and ethnic literature, especially Chilean literature. It can be said that this work shows its distinctive feature of being pioneering, research-oriented, objective, and dialectical.

\section{Being Pioneering}

Since the second half of the last century, the study of American multicultural literature has gradually become a prominent subject, and the scope of the study is expanding day by day, covering all ethnic literary branches of literature. With the deepening of the study of American Literature in China, the compilation of the history of American literature has entered a relatively prosperous period. Since the 1980s, more than ten types of American literature history books have been published, which fully demonstrates the attention to and achievements of American literature in the domestic academic circle. However, not all branches of American literature have received due attention, and Hispanic American literature is one of them. According to Li Baojie, the study of Western Ethnic literature is an important reference for the interpretation of the whole history of American literature and the orientation of American values (2012: 15). However, its research has just started until the beginning of this century, and the first problem it faces is the lack of systematic research on this branch of literature in China. The publication of the book is just at the right time and makes up for the research gap in this field. This may be seen as an example of American literary historian Robert Spiller's famous saying: "Every generation should write at least one history of American Literature” (1917, III). As the harvest work of the National Social Science Foundation Project (12bww048), Professor Li Baojie's lengthy monograph has 527 pages and took her eight years to complete. It can be read against her A Study on Contemporary American Latino Literature (2014), which was published several years ago. If we say A Study on Contemporary American Latino 
Literature is "the pioneering work of contemporary Hispanic American literature research in China" (Wang Zuyou, 127), then The History of Hispanic American Literature is a landmark masterpiece, which "focuses on tracing the origin of literary tradition", promotes the study of Hispanic American literature research to the depth of history, and expands to different ethnic branches of Hispanic literature, "including the representative English texts of the branches of Hispanic literature and some texts originally written in Spanish and then translated into English” (2012: 489). Using chronology and literary geography methods, The History of Hispanic American Literature makes a comprehensive study of American Spanish literature. "The horizontal study focuses on the geographical and cultural characteristics, social problems and cultural values in a specific historical period, as well as the more common ways of literary representation in various times; the vertical diachronic study takes the overall development and evolution of Hispanic literature as the basic context, and examines the track of its development and growth” (2012: 490).

\section{Being Research-oriented}

Generally speaking, literary history can be divided into two types: popular type and scholarly type. Popular literary history is known for easy understanding, clear and comprehensive narrative clues, systematic exactness, and explicit emphasis. It usually adopts the traditional narrative mode of "historical background + writers and works". Research-oriented literary history belongs to the category of literary history theory, and its readers are literary researchers. These readers hope to obtain new perspectives and discoveries about their own research field through reading literary history. Despite being highly academic, this kind of literary history may not attach much importance to the systematic exactness of narration and the consistency of views.

Of course, there are two types of American literary history written in Chinese. Considering the readers of the history of American literature and the current situation of American literature research in China, the history of American literature that we need now should be a combination of both popular and scholarly kinds. We should not only systematically describe the history of American literature, but also provide new academic insights instead of banal views. This is what The History of Hispanic American Literature strives to achieve. The writing principle of The History of Hispanic American Literature is to systematically sort out all categories of American Hispanic literature from the perspective of history and ethnicity, and focus on its writing theme, literary paradigm, presentation and developmental trend (2012: 489). The branches of Hispanic literature have a high degree of heterogeneity, but they also have some similarities. On the premise of paying attention to the differences of ethnic literature, Hispanic literature focuses on the similarities of various branches of literature and traces the history of literature. For example, in order to trace the development of Mexican Literature, it includes Maria Lewis, the first English writer and two literary pioneers at the turn of the 19th and 20th centuries: Eusebio ChacÓn and Leonor Villegas de MagnÓn. That is to present a relatively complete development track for the literary reproduction of the theme of cultural conflict. In this way, the relatively clear distinction between criticism and research, aesthetic analysis and historical analysis in the past has been blurred (1989: 2). The History of Hispanic American Literature is undoubtedly in line with the expectations of Chinese readers in their reading of literary history.

As a matter of fact, The History of Hispanic American Literature is not just a review of the history of ordinary literature, but its research has shown its eminence from the very beginning, such as the in-depth analysis of the connotation and extension of the concepts of "Hispanic" and "Latino" and the distinction between 
“Hispanic American Literature” and “American Hispanic Literature”, i.e., "Hispanic American Literature” uses "Hispanic" as a modifier and distinguishes American literature by residential area; "American Hispanic Literature" takes "America" as a modifier and American literature as a context, emphasizing that "Hispanic" literature is a branch of American ethnic literature (2012: 4). Playwright Maria Irene Fornes' Manual for a Desperate Crossing (1996) is based on the "rafters' accident" around 1994. The History of Hispanic American Literature comments on the design of symbolic reference of characters in the play: the purpose of designing characters in this way is to show the uniqueness of characters and objects in the play. The symbolic reference also implies the materialization of characters. Their individual emotional and spiritual demands are weakened, which implies the insignificance of individual life and the meaninglessness of characters' survival in the context of life politics of immigration tide. This clearly shows that Fornes' works go beyond female writing and individual trauma narrative to "exploring the meaning of life in a broader perspective" (Li Baojie 2012), thus representing an important voice in American drama in the early 1990s. Dolores Prida inherits Maria Irene Fornes' avant-garde drama tradition obviously in the form: "the prominent features of Prida's drama are the use of Latin American cultural elements and the Hispanic characters in the bilingual background. By portraying these Hispanic characters with a strong Spanish accent in American society, she represents the survival and spiritual demands of the Hispanic people and writes about the Hispanic version of the American Dream" (2012: 332). Such intensive reading and comparative study are common in the book. Readers with a wider vision will also find that a considerable part of the content of the chapters in The History of Hispanic American Literature has been published as independent academic papers in professional journals and magazines, but there are subtle differences in the presentation of the chapters in The History of Hispanic American Literature, so as to conform to the academic orientation of "literary history", which shows the author's intention of academic research. The author's respect for academic research can be seen from a sentence in the postscript of The History of Hispanic American Literature: "for fear that my logic may not be clear, argument not rigorous, and my wording not appropriate" (2012: 527).

\section{Being Objective}

In the research of specific writers' works, this book interprets the works of representative writers through close reading and examines and judges their literary status and achievements within the framework of the whole of ethnic literature. Alejandro Morales (1944-) was one of the most creative and famous writers in contemporary Chicano literature, the real leader of contemporary Chicano literature, and the mentor of Dr. Li Baojie when she was a visiting scholar in the United States. Politics and ethnicity are the primary consideration when Morales chooses historical themes. Therefore, Alejandro Morales' historical novels are based on social reality, reflecting the contemporary Chicano writers' sense of responsibility and political responsibility. Morales used the historical narrative to write about the group memory and trauma of Mexican Americans so that those Mexican Americans who had made contributions to American society could be remembered and recognized again. In this regard, the book points out: "the typical style of Morales is the combination of realism and magic realism." (2012: 145). The purpose of Morales is to reveal the relationship between the colonial history of Latin America and contemporary disasters. As for the historical themes of his novels, this book holds that his works are permeated with strong historical consciousness and contemporary reference. In order to express his deep concern about the future of Mexican ethnic groups: "Morales' novels are, in the final analysis, the expression of ethnic politics" 
(2012: 148). Part of the reason why this kind of "depoliticized" work did not receive timely attention in the early years is that the expression of "power relations" in the text tends to be diversified or obscure. From another point of view, the diversity of literary writing brings lasting vitality to literature. "Among them, the political influence is no less than that of the works related to the theme of "Aztland" in the period of Chicano Movement, but its appeal way is more "hidden" (2012: 149). "depoliticization by Morales and other writers provides a possible way out for Chicano literature to get rid of the narrow nationalist orientation and gain more extensive recognition” (2012: 150).

In the study of contemporary Cuban American literature, the term "exile" has a specific political and historical implication, namely the Cuban revolution. After the Cuban Revolution of the 1950s, the change of new and old political power and the change of ideology led to the first wave of immigration from 1959 to 1962 . The History of Hispanic American Literature focuses on "Exile literature" and emphasizes that it is a literary narration of the exile's immigration experience. Taking the first-generation exile writer Carlos Alberto Montaner as an example, it points out that the exile transforms his personal experience into political capital and writing capital through literary narration, Journey to the Heart of Cuba: Life as Fidel Castro (2001) is to achieve the purpose of voicing by "consuming Cuba" and "consuming Castro", which has strong ideological expression and obvious commercial flavor.

In the overall consideration of exile literature, The History of Hispanic American Literature states:

In order to protect their own interests, exile literature and its literary subject will suppress different voices, which to a large extent inhibit other literary writing modes. If the writer fails to express his clear political position and oppose Castro's regime in his works, he will be regarded as an alien in the Cuban community and may be restricted by the powerful Cuban American mainstream discourse. Due to the lack of anti-Communist political stance, the planned recitation was canceled; Garcia was accused of being a communist; Prida was strongly boycotted when his play Calm Waves was performed in Miami in 1986 because he sympathized with the Cuban authorities. The purpose of this effort of the Cuban American mainstream is to "ensure that other voices or identities that do not conform to the single Cuban identity or Cuban American identity are excluded and suppressed." Of course, these examples are not rare cases. The literary works of exile mode have become the mainstream of Cuban Americans in South Florida. This hegemonic discourse cannot tolerate the voice of disharmony at present and even plays with the theme of cultural conflict, and cultural identity reconciliation cannot be accepted by it. (2012: 373 )

The writing of Exile Literature binds “exile" with political ambition and historical mission. When they write historical themes, they agree with or even cater to the political activities launched by overseas Cuban exiles to subvert the Cuban regime, which makes literature writing instrumental. The success of the writing mode of Exile Literature partly lies in that it caters to the expectations of American society. However, when it becomes the mainstream of Cuban American literature and suppresses different voices in Cuban American literature, its hegemonic position makes it deviate from its original intention and contradict its proclaimed "freedom" and "democracy”. Reinaldo Arenas is a case in point. Reinaldo Arenas is regarded as one of the most influential Cuban exile writers. His writing of "exile" is reflected in the combination of personal history and Cuban history. Reinaldo Arenas thinks that his writing in exile is just a label of personal appeal, "projecting self-value in the struggle against various powers, even at the expense of other interests, including literariness.” (2012: 386$)$. 
Reinaldo Arenas's extreme viewpoint lies in "his excessive attention to political themes has greatly damaged the literariness of his works and greatly reduced the literary value of his works” (2012: 389).

\section{Being Dialectical}

The History of Hispanic-American Literature shows strong dialectical conscientiousness, especially in the part of Cuban literature. In the controversial literary criticism of exile, this book focuses on clarifying different critical voices. Arenas thinks that his literary achievement lies in his historical writing, but The History of Hispanic American Literature has different concerns. The author of The History of Hispanic American Literature thinks that the theme of homosexuality instead of the historical writing is what is worth giving utmost attention to in Arenas' Antes que anochezca (1992). Prof Li also cites the studies of Rafael Ocasio, Francisco Soto and Jorge Olivarez and their own judgment made through the different aspects of Arenas'works, pointing out that these critics have not limited their critical vision to the “current Cuba” described by Arenas' or Cuba during Castro's period, "and this critical perspective is what actually separates a literary writing from political discourse, which improves the literary significance of Arenas' works to a certain extent" (2012: 385). Then it criticizes the writing of the exiled writers such as Arenas. The author thinks that the exile experience of the writers makes the political writing of the exile literature express the appeal and arouse the attention in the specific historical period. However, the literariness guarantees the vitality of the works, and only by considering the two can we obtain lasting vitality. To a certain extent, the acceptance of the critics provides an opportunity for the second generation of Cuban immigrant writers to turn direction in their exile writing.

Based on this, The History of Hispanic American Literature traces the presentation and evolution of the theme of exile literature in different times, focusing on the change of political representation. The theme of exile in the early stage shows a relatively simple ideological feature, and the process of exile is the focus of the writing. In the 1.5 generation of Cuban immigrant writers, exile writing began to combine with personal growth, using the form of life writing to reproduce the model image of Cuban immigrants; this kind of writing also has more literariness, which has been widely recognized by mainstream cultural groups in the United States. In Waiting for Snow in Havana: Confessions of a Cuban Boy, Carlos Nieto Eire (1950-) combines his exile experience with his personal mental growth in the form of memoir, which " not only caters to the writing paradigm of exile mode, but also weakens his political expression and highlights his literariness through artistic processing, which is also the fundamental reason why his works can stand out from many exile literary works" (2012, 392). However, the theme of exile not only constructs its discourse authority, but also gives birth to the voice of opposition. Cristina García's first novel, Dreaming in Cuban (1992), is the first Spanish American literary work nominated for the National Book Award. In King of Cuba (2013), she inherited the historical theme and selected the exile theme prevailing in Cuban American literature, but clearly expressed her counter exile position. After more than half a century of development, Cuban American exile literature combines the political theme, identity and cultural negotiation with the "American Dream" to show the different levels of the identity of Cuban immigrants and Cuban Americans. In addition to the "exile” identity, Cuban Americans also have other ways of self - construction. When expounding the epochal features of Mexican American bildungsroman in the new century, The History of Hispanic American Literature not only recognizes the common themes, but also points out these generational differences and changes in the writing paradigm.

Another manifestation of the dialectical nature of The History of Hispanic American Literature is its concern 
for the contemporary Mexican American bildungsroman, especially its life writing paradigm, which points out the political metaphor of life. Jimmy Santiago Baca and Luis J. Rodriguez focus on describing the problems of street gangs and juvenile delinquency faced by middle and lower class Mexican teenagers in their growth. Garry Soto and Domingo Martinez write about the growth of Mexican Americans in the community. Reyna Grande's writing focuses on the experience of immigration, especially the protagonist's experience of crossing the border and gradually adapting to the new life as an illegal immigrant. Using a variety of narrative strategies, they emphasize the connection between class and race and use non-fictional narrative forms such as "memoirs" or "autobiography" to increase the credibility of the narrative. They also provide a variety of epochal themes for life writing in today's minority literature (2012: 196). All of these can be the topics for further development in this field, even in minority literature research.

When commenting on the representative Chilean writers Isabel Allende and Ariel Dorfman, the author, while acknowledging the social influence and cognitive value of their works, questions their status in the history of literature, reflecting a high degree of dialectical thinking: "what is the literariness and vitality of these works? It will take time to test. Perhaps it is in a similar consideration that Allende also began to show a trend of diversification in writing, expanding from women's growth and historical themes to American themes represented by Alexander Cod series. Dorfman also gradually transcended the literary geographical field of Chile, blended different techniques and historical backgrounds, and explored a more aesthetically expressive political narrative. ” (2012:488) It takes courage to question famous living writers.

In a word, taking ethnicity as the main-line, highlighting the political demands of literary writing, The History of Hispanic American Literature interprets the value orientation and aesthetic expression in literature by relying on the text and makes a comprehensive investigation of representative writers' works under the framework of society, history, literature and art through intensive reading of typical texts. This work is the result of years of hard work. It reflects the political and cultural literacy of Chinese scholars. If I were pressed with a requirement to make a suggestion, I think, as the author mentioned in the postscript, that "there are obvious differences in the degree of detail of different literary branches, and the collation of writers' works is inevitably biased, and there may even be omissions” (2012: 526). For example, Lorna Dee Cervantes ( 1954 - ), the Chicana Aboriginal poet, was omitted probably due to the poet's Aboriginal identity; but in fact, Cervantes was an active participant in the political and cultural movements during the Chicano Movement. After all, The History of Hispanic American Literature is the first comprehensive and systematic study of American Hispanic literature. It has made an unprecedented contribution to the study of American Literature in China and will open a new era for the historiography of American Hispanic literature as well.

\section{References}

Sacvan, B. (Ed.). (1989). Cambridge history of American literature. Cambridge: Cambridge University Press.

LI Baojie.(2012). The history of Hispanic American literature. Jinan: Shandong University Press.

William, T. (Ed.). (1917). The Cambridge history of American literature. Cambridge: Cambridge University Press.

WANG Zuyou. (2015). A pioneer work in American Latino literature studies: Reviewing A Study on contemporary American Latino literature. World Literature Studies, 3, 127.

(Editor: Jasmine) 